\title{
Influence of limestone dust and natural pozzolan on engineering properties of self-compacting repair mortars
}

\author{
Amar Benyahia, Said Choucha, Mohamed Ghrici \\ Geomaterials Laboratory, Hassiba Benbouali University of Chlef, Algeria \\ a.benyabia@univ-chlef.dz,said_choual@hotmail.fr,m.ghrici@univ-chlef.dz.
}

\author{
Ahmed Omran \\ Department of Civil Engineering, University of Sherbrooke, Canada \\ a.omran@usherbrooke.ca
}

\begin{abstract}
The main goal of this work is to develop self-compacting repair mortars (SCRMs) containing limestone dust (LD) and Natural Pozzolan (NP). Therefore, a three different mortar (SCRM0, SCRM-10LD and SCRM-20NP) were prepared and tested according to EN 1504-3. The results of the experimental study showed that the produced repair materials fulfilled the performances requirements for structural repair products, class R4. In addition, complete composite specimens for the slant shear, showed a good bond strength between the SCRMs and existing substrate concrete (SUBC) at 28-days and the fractures were only occurred in the SUBC, which means that the substrate is the weakest link in the repair system.
\end{abstract}

KEYWORDS. Self-compacting mortar; Limestone dust; Natural pozzolan; Composite; Bond strength; Repair.

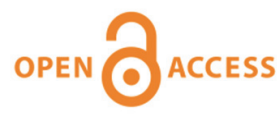

Citation: Benyahia, A., Choucha, S., Ghrici, C.., Omran, A., Influence of limestone dust and natural pozzolan on engineering properties of self-compacting repair mortars, Frattura ed Integrità Strutturale, 45 (2018) 135-146.

Received: 05.02 .2018

Accepted: 07.06.2018

Published: 01.07.2018

Copyright: (C) 2018 This is an open access article under the terms of the CC-BY 4.0, which permits unrestricted use, distribution, and reproduction in any medium, provided the original author and source are credited.

\section{INTRODUCTION}

$\mathrm{I}$ $\mathrm{n}$ the last decades, the number of houses in the developing countries has increased dramatically due to the increase in the average income. These structures should be preserved in good conditions for longer life spans by carrying out periodical maintenance and rehabilitation. If the structures are made of concrete, high quality of care should be given, because concrete deterioration can be caused by a variety of factors, including natural hazards, climate changes, overloading, etc. These conditions could result in corrosion, cracking, local damages, or in extreme cases which can all lead to concrete failure However a crack maybe the first sign of a serious defect which may affect the serviceability or the stability of the building [1].

The cracks can be prohibited or at least minimized by the inclusion of fibers in the cementitious matrix. Fibers can improve several mechanical properties of the hardened mortar such as post-cracking response, toughness, flexural strength and ductility; they can also reduce the water permeability and the creep [2]. Currently, there are a large variety of 
fiber options for reinforcing concrete, available in the marketplace including steel, glass, synthetic, and natural fibers. Among them, the polypropylene fibers (PPF), as one of the synthetic fibers, is the most frequently used type due to its affordable cost, better distribution in concrete, and avoidance of corrosion spots on the concrete surface which could be made by using the steel fibers. Singh et al. [3]. reported that the fracture, impact resistance toughness and fatigue properties can be improved significantly when using polypropylene fibers in the cement mortar mixture. However, the fiber addition can reduce the mortar workability. The better dispersion of fibers in a mortar and more workability characteristics are the key factors to obtain successful fiber-reinforced mortar for repair applications [4].

The self-compacting mortar mixture (SCM) can provide many advantages. Self-compacting mortar, as the name indicates is a highly flowable mortar which can be placed without any external consolidation [5]. Nowadays, the self-compacting mortar is specially designed for repair applications [6]. The SCRM technology can provide better filling capacity, especially in the heavily reinforced sections and the narrow spaces [7, 8].

The SCMs mix requires a significant amount of mineral admixtures content compared to the ordinary mortar [9]. The use of mineral admixtures in self-compacting mortars mix can improve rheological and mechanicals properties and durability. Since that cement is one of the most expensive components of concrete or mortar, the use of mineral admixture as a replacement of cement is one of the economic solutions. However, mineral admixtures are not available in all regions and would be expensive if imported which makes their imports more expensive. This promotes the valorization of other available local materials (natural, waste or by-products) which can be used as mineral additives for the production of repair materials. Therefore, due to their high availability in Algeria, limestone dust (LD) and Natural Pozzolan (NP) could be successfully and economically used as mineral admixtures in self-compacting mortar production.

During extraction and processing of limestone rocks, huge amounts of fines called limestone dust (LD) are generated forming unsold stocks. Therefore, in the presence of wind, these fines are transported and can affect the health workers as well as the people living near quarries [10]. Incorporation of limestone dust in construction works will solve the problem of disposal of these fines. Limestone dust has been successfully used in concrete or mortar as a sand replacement. However, few researches have been conducted in the area of SCC using this fines as a partial cement replacement. Zhu and Gibbs[11]. observed that incorporating limestone powder in SCC can accelerate cement hydration and improve the early strength. Chi et al., 2004 reported that it is possible to use up to $15 \%$ of limestone fines in concrete manufacture without compromising its mechanical strength. Felekoglu et al. [12]. investigated the effect of quarry dust on SCC mix. They stated that quarry dust powder reduced the superplasticizer content and enhanced the 28-day's compressive strength. Dehwah [13]. reported that using of quarry dust in SCC mix enhances their mechanical properties.

Natural pozzolans are siliceous or siliceous and aluminous materials produced during magmatic eruptions. These materials do not harden themselves when mixed with water, but when finely ground the desired fineness and in presence of water, they react with dissolved calcium hydroxide $\left(\mathrm{Ca}(\mathrm{OH})_{2}\right)$ at ordinary temperatures to form strength-developing calcium silicate (C-S-H gel) and calcium aluminate compounds. Natural pozzolans have been used successfully since a long time as cement replacement in concrete industry for many purposes to bring down the cost of OPC [14] as well as to produce more environmental friendly concretes [15]. In addition, its engineering properties have been also subjected to investigation $[16,17]$. Indeed, these materials have been used to reduce the hydration heat evolution and to increase strength and durability characteristics of mortar. But only a few studies[18-21 ] were carried out to investigate the effect of natural pozzolans on SCC .

The main goal of this research is to develop self-compacting repair mortars with available local materials such as limestone dust and natural pozzolan, and the study of the engineering properties behavior of the produced repair materials.

The main goal of this research is to investigate the engineering properties behavior of self-compacting repair mortars made by the available local materials such as limestone dust and natural pozzolan.

\section{MATERIALS, MIXTURE PROPORTIONS AND TESTING METHODS}

\section{Materials used}

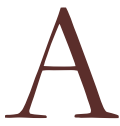

ll the repair mortars mix were prepared using ordinary portland cement CEM I 42,5 in accordance with EN 1971[22]. The chemical composition and physical characteristics of OPC were obtained from the lab result and given in Tab. 1. Two types of local mineral admixtures; limestone dust and natural pozzolan were used. These materials were milled to a particle-size distribution with a mean-particle diameter $\left(\mathrm{d}_{50}\right)$ of $125 \mu \mathrm{m}$. Tab. 1 also presents the chemical composition and physical properties of these two fillers. Modern superplasticizers based on chains of modified polycarboxylic ethers in accordance with EN 934-2 [23], with a solid content of $30 \%$ and density of $1.065 \mathrm{~g} / \mathrm{cm}^{3}$ was used. A short PPF fiber with a length of $12 \mathrm{~mm}$, diameter of $0.3 \mathrm{~mm}$, modulus of elasticity of $3 \mathrm{kN} / \mathrm{mm}^{2}$ and density of 
$0.9 \mathrm{~g} / \mathrm{m}^{3}$ was used. Coarse aggregates used in the formulations of repair materials mix were crushed limestone gravel, with Dmax of $15 \mathrm{~mm}$ and specific gravity of 2.56. Siliceous river sand, with a specific gravity of $2.42, \mathrm{Dmax}$ of $3 \mathrm{~mm}$ and fineness modulus of 1.65 was used. Particles size distribution of coarse and fine aggregates are also presented in Fig.. 1.

\begin{tabular}{cccc}
\hline Physical properties & Cement & Limestone Dust & Pozzolan \\
Specific gravity & 3.10 & 2.72 & 2.63 \\
Specific surface area $\left(\mathrm{m}^{2} / \mathrm{kg}\right)$ & 350 & 470 & 550 \\
Compressive strength (MPa) & 42.5 & - & - \\
Chemical properties (\%) & & & \\
$\mathrm{CaO}$ & 63.91 & 52.57 & 10.88 \\
$\mathrm{SiO}_{2}$ & 21.58 & 4.58 & 48.1 \\
$\mathrm{Al}_{2} \mathrm{O}_{3}$ & 4.44 & 0.41 & 18.83 \\
$\mathrm{SO}_{3}$ & 1.93 & 0.01 & 0.51 \\
$\mathrm{Fe}_{2} \mathrm{O}_{3}$ & 5.36 & 0.42 & 10.6 \\
$\mathrm{MgO}_{\mathrm{Na}} \mathrm{O}$ & 1.64 & 0.22 & 4.38 \\
$\mathrm{~K}_{2} \mathrm{O}$ & 0.11 & 0.01 & 0.80 \\
Loss of ignition & 0.22 & 0.13 & 0.20 \\
\hline
\end{tabular}

Table 1: Characteristics of ordinary cement, limestone dust and natural pozzolan.

\section{Mixture proportions}

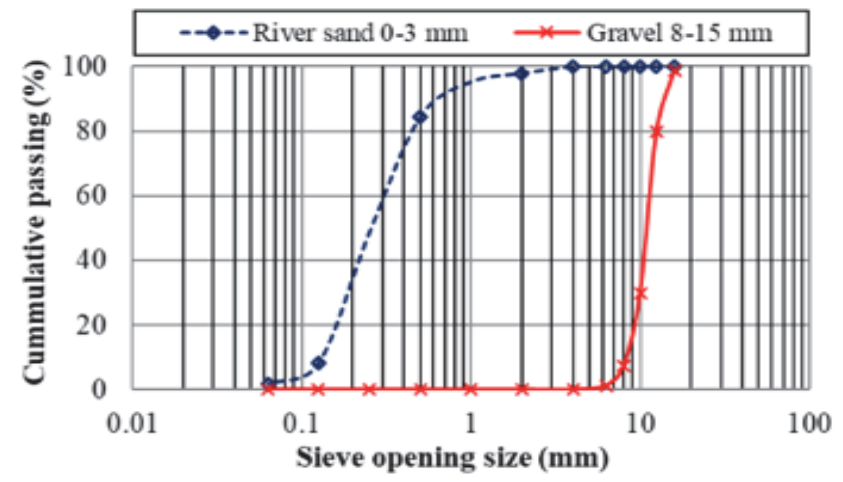

Figure 1: Grading of gravel and sand.

In order to evaluate the influence of local mineral admixtures on the properties of repair mortar (SCRMs), Two types of mortar mixtures containing 10\% LD and 20\% NP as partial OPC replacements were prepared in comparison with a control mortar (Tab. 2). The water-to-powder ratio and the volume fraction of polypropylene fibers were kept constant in all the SCRMS mixtures. Appropriate adjustments were conducted in the amount of SP in each mixture to achieve rheological properties as recommended by the EFNARC (2005). The substrate concrete (SUBC) is an ordinary Portland cement concrete usually used in the construction. The mix proportion of the SUBC is also presented in Tab. 2.

\begin{tabular}{ccccccccccc}
\hline $\begin{array}{c}\text { Repair } \\
\text { materials }\end{array}$ & Cement & LD & NP & P & Water & Sand & Gravel & W/P & SP & PPF \\
SCRM-0 & 685 & 00 & 00 & 685 & 260 & 1274 & -- & 0.38 & 7.55 & 1.2 \\
SCRM-10LD & 616.5 & 68.5 & 00 & 685 & 260 & 1274 & -- & 0.38 & 6.50 & 1.2 \\
SCRM-20NP & 548 & 00 & 137 & 685 & 260 & 1274 & -- & 0.38 & 8.45 & 1.2 \\
SUBC & 340 & -- & -- & -- & 170 & 720 & 1130 & 0.5 & -- & -- \\
\hline
\end{tabular}

Table 2: Mixture proportions of SCRMs and SUBC $\left(\mathrm{kg} / \mathrm{m}^{3}\right)$. 


\section{Testing methods}

The self-compactness characteristics of all the repair materials mix were evaluated by using a mini-slump flow and mini-Vfunnel flow time tests according to EFNARC [24]. The Mini slump-flow was used to describe the ability of the fresh mix to deform under its own weight in unconfined conditions. The Mini V-funnel flow time can be used to evaluate the flowability or viscosity of the repair materials mix. The fresh unit weight of repair mortars was determined according to EN 1015-6 [25]. Compressive and flexural strengths tests of SCRMS samples were conducted in accordance to EN 121906 [26]. Three prism specimens measuring $40 \times 40 \times 160 \mathrm{~mm}$ was cast for both compressive and flexural strengths, for each repair mortar. All the repair mortars samples were demolded and tested in the laboratory after 1,7 and 28 days. The mechanical properties of substrate concrete (SUBC) such as compressive and splitting-tensile strengths were determined on $100 \mathrm{~mm}$ diameter and $200 \mathrm{~mm}$ height cylinder specimens after 28-days. The flexural strength test was determined on $70 \times 70 \times 280 \mathrm{~mm}^{3}$ beam samples at 28 days. The dynamic modulus of elasticity for all the repair mortars was determined after 28 days by the resonant frequent method using the ultrasonic pulse velocity test [27] (Fig. 2).

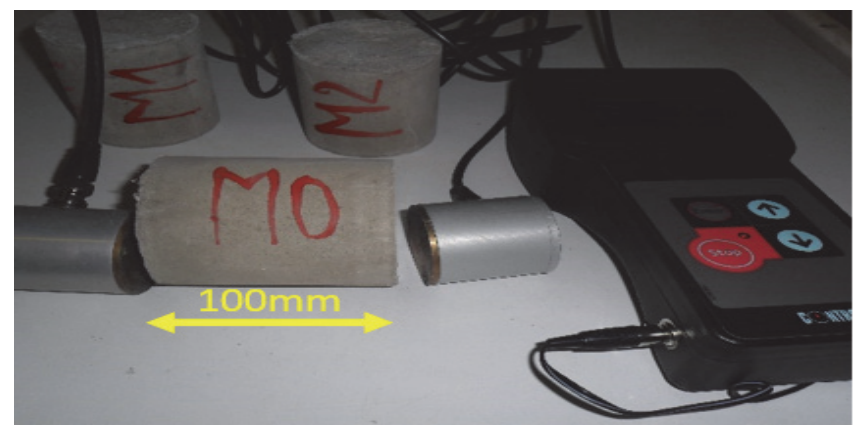

Figure 2: Test on dynamic modulus of elasticity of SCRMs samples.

The specimen was a cylinder with a diameter of $50 \mathrm{~mm}$ and height of $60 \mathrm{~mm}$. After determining the ultrasonic velocity through the specimen, the $\mathrm{E}_{\mathrm{D}}$ is calculated as follow:

$$
\mathrm{E}_{\mathrm{D}}=\varrho \mathrm{v}^{2}
$$

where, $\mathrm{E}_{\mathrm{D}}$ is the elastic modulus ( $\left.\mathrm{GPa}\right)$, $\varrho$ is the density of the dry samples $\left(\mathrm{kg} / \mathrm{m}^{3}\right)$ and $\mathrm{v}$ is the ultrasonic velocity $(\mathrm{m} / \mathrm{s})$. In order to evaluate the durability characteristics of the produced repair mortars, the capillary water absorption coefficient was measured according to EN 1015-18 [28]. After 28-days of curing, the SCRMs prism specimens $(40 \times 40 \times 80 \mathrm{~mm})$ were introduced in the oven at $60^{\circ} \mathrm{C}$ until mass stabilization. A resin layer covered the lateral sides of the prisms. The dry mass of the prisms was noted, where these prisms were vertically placed over a grid in a watertight tray containing $5 \mathrm{~mm}$ water depth. The capillary water absorption coefficient of the mixtures at 28 days was calculated as follows:

$$
\mathrm{C}=\frac{\mathrm{M}}{\mathrm{A} \sqrt{\mathrm{t}}}
$$

The adhesion between produced repair materials (SCRMs) and concrete substrate (SUBC) was evaluated by the slant shear test procedure according to ASTM-C882 [29]. The quantification of bond strength by this test was justified by the excellent results reported in previous studies [30,31]. In the slant shear test, each type of repair mortar was bonded to a substrate concrete sample which has slant plane inclined at $30^{\circ}$ angle from vertical axis. It should be noted that before casting the repair materials, the concrete substrates were surface treated by the sandblasting then by dry brushing to ensure a better bond strength [32,33]. The composite samples were $76 \mathrm{~mm}$ in diameter and $152 \mathrm{~mm}$ in height thus obtained (see Fig. 3) were tested under a compressive load using the conventional procedure according to ASTM C39 [34].

The bond strength can be calculated as follow:

$$
\mathrm{S}=\frac{\mathrm{F}_{\max }}{\mathrm{A}}
$$


where, $\mathrm{S}$ is the bond strength $(\mathrm{MPa})$, Fmax is the maximum applied compressive force $(\mathrm{kN})$ and $\mathrm{A}$ is the area of the interface. The slant surface area is given:

$$
\mathrm{A}=\frac{\pi \cdot \varnothing^{2}}{4 \cdot \sin 30}
$$

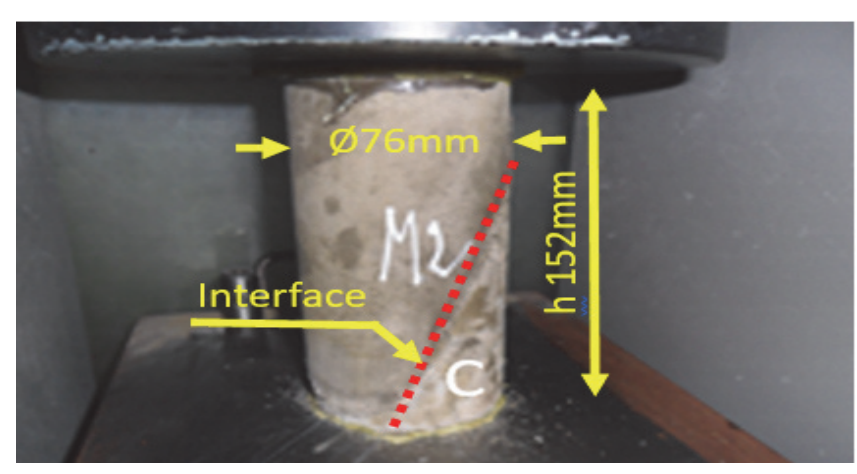

Figure 3: Composite cylinder samples subjected to slant shear.

\section{RESULTS AND DISCUSSION}

Mini-slump flow

7 he results of the mini-slump flow test for all tested repair materials mixtures are plotted in Fig. 4. All a repair mortars were designed to satisfy the requirement of SCMS limits [24], which were obtained by adjusting the content of the SP. It can be seen from the Fig. 4 that mixtures containing 10\% LD showed a better flowability when compared to the mixture containing $20 \% \mathrm{NP}$. The required amount of SP to achieve the target flowability for SCRM-10 LD decreased by 0.9 liters compared to the control mortar mix (see Tab. 2). This can be explained by the higher fineness of the LD filler particles compared to the cement, which improves the packing density of cement, leading to decreasing the retained water in the mortar skeleton. This was also reported by several researchers such as Fujiwara et al. [35] and Ellerbrock et al. [36]. However, SCRM-20NP mix required a slightly higher amount of SP (1.05 liter) than that used for the SCRM0 mix to achieve the desired flowability. This behavior can be attributed to the higher fineness and the irregular particles shape of NP. This also confirms the results of previous works on the natural pozzolan [37-39].

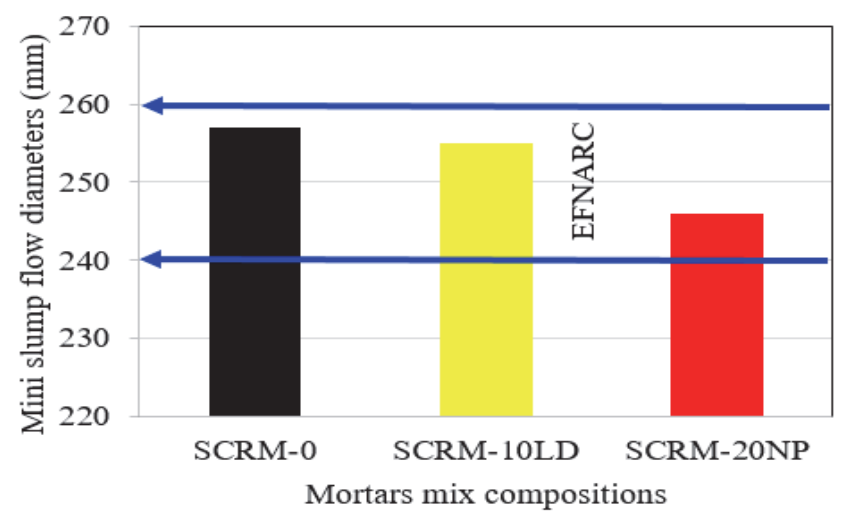

Figure 4: Mini-slump flow for SCRMs.

\section{Mini V-Funnel flow time}

The flow time results obtained from the mini V-Funnel showed that the observed values for all SCRMs mixtures are included in the EFNARC specifications (Fig. 5). The incorporation of 10\% LD in the SCRM1 mix resulted in a flow time 
very close then that of control mortar mix. In contrast, the SCRM-20NP mixture showed a slightly higher flow time. This is in agreement with previous works $[40,18]$.

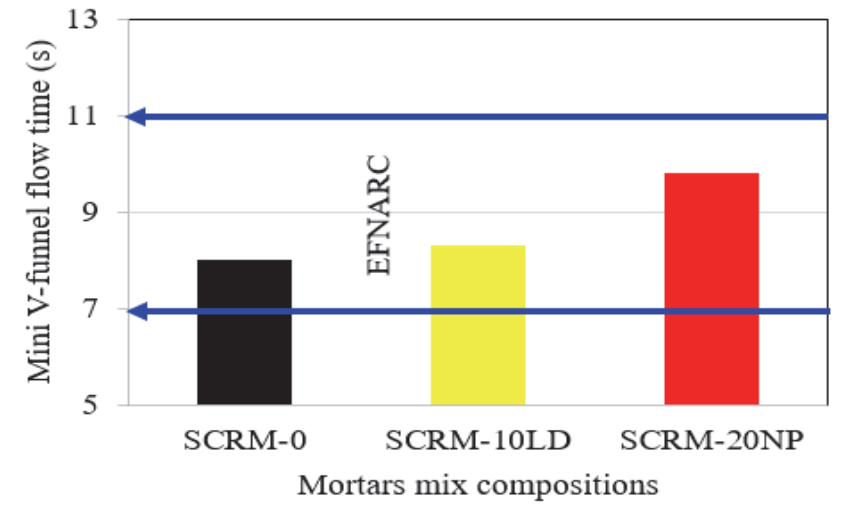

Figure 5: Mini V-Funnel flow time for SCRMs.

\section{Fresh unit weight}

The measured unit weight values for the SCRM-0, SCRM-10LD and SCRM-20NP mix were 2210, 2115, and $2193 \mathrm{~kg} / \mathrm{m}^{3}$, respectively. From these results, it can be seen that cement replacement with 10\% LD and 20\% NP yielded about $4.3 \%$ and $1.0 \%$ reduction in the density for fresh SCRM-10 and SCRM-20NP mix respectively, compared to that of the control mortar mix. This was due to the lower density values of the LD and NP particles compared to the cement particles (see Tab. 1). Cement replacement with 10\% LD in the SCRM-10LD mix did not increase fresh density compared to that obtained by $20 \% \mathrm{NP}$ in the SCRM-20NP, despite the density of the LD which was higher than that of the NP. This can be justified by the higher fineness of the NP particles $\left(550 \mathrm{~m}^{2} / \mathrm{kg}\right)$ compared to that of the LD $\left(470 \mathrm{~m}^{2} / \mathrm{kg}\right)$ which led to a higher matrix densification of SCRM-20NP.

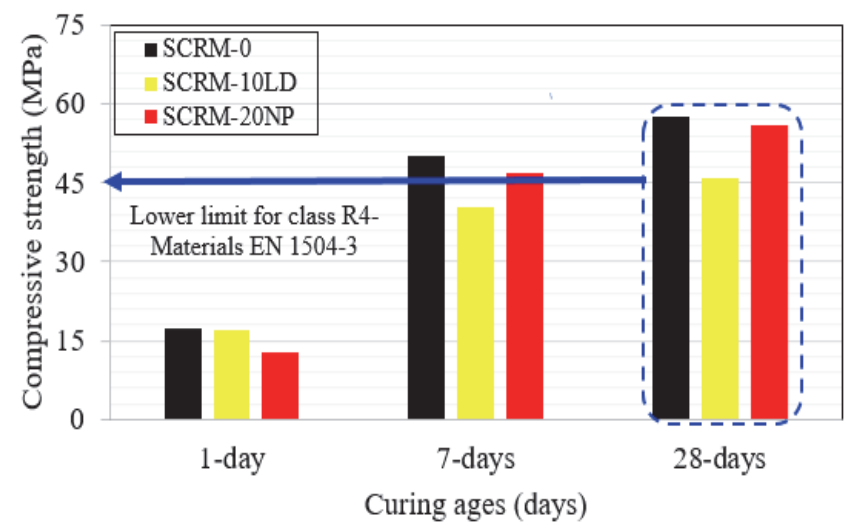

Figure 6: Variation of compressive strength with age for SCRMs.

\section{Compressive strength}

Fig. 6 shows the measured compressive strength of produced repair mortars (SCRMs) at 1, 7 and 28 days. The compressive strength of mortar mix containing 10\% LD and 20\% NP was lower than that of the control mortar mix at all ages. The highest compressive strength was obtained by the control mortar mix, followed by the mortar containing $20 \% \mathrm{NP}$ and then that containing 10\% LD. Except for 1-day of curing, the compressive strength of SCRM-10 LD was close $(16.87 \mathrm{MPa})$ to that of the control mortar $(17.34 \mathrm{MPa})$ but exceeded that of the SCRM-20NP (12.81MPa). This result is consistent with previous studies [41, 16]. This behavior can be attributed to the fact that hydration provides/produces monocarbo-aluminate, when the finely limestone dust $\left(\mathrm{CaCO}_{3}\right)$ reacts with $\mathrm{C}_{3} \mathrm{~A}$ [42, 43]. Moreover, the decrease in the compressive strength of the SCRM-20NP at 1-day can be attributed to the slowness of the pozzolanic reaction [44].

However, the strength gain was more pronounced for SCRM-20NP-beyond 7 days of curing. The compressive strength of SCRM-20NP was $47 \mathrm{MPa}$ and continues to increase and reached $56 \mathrm{MPa}$ at 28-days of curing which was slightly lower 
than those of the control mixture $(57.6 \mathrm{MPa})$. This can be attributable to the higher rate of C-S-H gel formed during cement hydration $[45,46]$. However, when the curing age extends from 7 to 28-days, the strength gain for SCRM-10LD was only $13 \%$. Further, at 28 days, the compressive strength of SCRM-10LD was $20 \%$ lower that that of the control mixture. The compressive strength reduction of SCRM-10LD can be attributed to the lower fineness and the slowness of the pozzolanic reaction of the LD (see Tab. 1) compared to that of the NP [47]. In addition, Fig. 6 shows that all the produced repair materials have high compressive strength values which can meet the requirement for class R4 specified by the EN 1405-3 [48].

\section{Flexural strength}

The results of flexural strength of repair mortars at 1, 7 and 28-days are shown in Fig. 7 . It can be seen that both compressive strength and flexural strength development show a similar trend. For instance, at 1-day of curing, the flexural strength of SCRM-20NP is approximately 20\%, higher than that of SCRM-10LD. However, for SCRM-10LD mixture, no significant flexural strength gain was observed beyond 7-days. This result was in accordance with the findings-reported by [9]. In addition, at 28-days of curing, using 20\% NP in SCRM-20NP mix showed flexural strength values very close (9.1 $\mathrm{MPa})$ to that of SCRM-0 (9.5 MPa). The increase in SCRM-20NP strength can be explained by the improvement of the aggregate (sand)-paste bond due to the densification of the transition zone (ITZ) and the formation of more secondary CS-H gel [41].

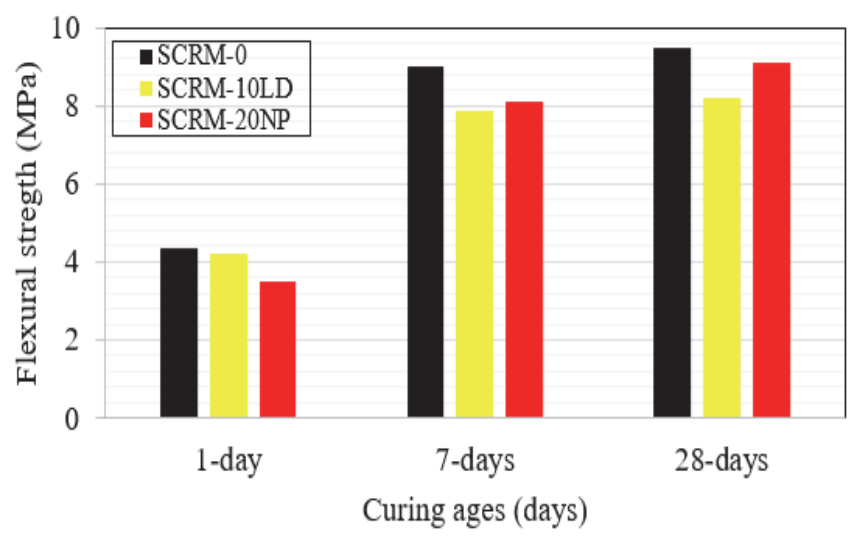

Figure 7: Variation of flexural strength with age for SCRMs.

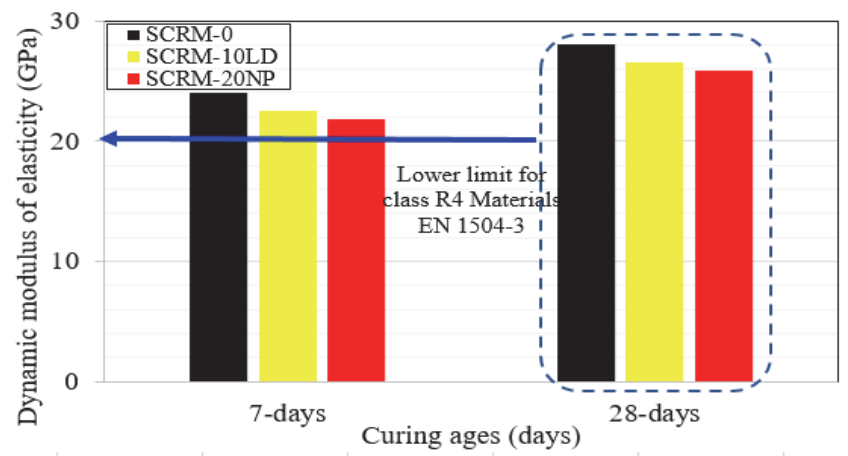

Figure 8: Variation of dynamic modulus of elasticity with age for SCRMs.

\section{Dynamic elastic modulus}

For all repair mortars, the dynamic elastic modulus $\left(E_{D}\right)$ for all repair mortars was measured at 7 and 28 -days and the results are presented in Fig. 8. In general, the results clearly showed the effect of mineral additions on the development of the $E_{D}$ with time. The obtained results showed that the $E_{D}$ decreases with increasing the replacement rate of cement by LD and NP. The highest modulus values were obtained by the control repair mix at all ages, due to the high amount of cement content ( $0 \%$ replacement). The 7 and 28-days $\mathrm{E}_{\mathrm{D}}$ values determined for the SCRM-10LD were $6 \%$ and $9 \%$ 
respectively, lower than those measured for the SCRM- 0 . The corresponding reductions for the SCRM-20NP were 5\% and $8 \%$. This finding was consistent with that obtained by [49]. In summary, the $\mathrm{E}_{\mathrm{D}}$ of SCRM-0, SCRM-10LD and SCRM-20NP at 28-days are 28GPa, 26.5 GPa and $25.8 \mathrm{GPa}$ respectively, which were higher than the lower limit $(20$ GPa) required by the EN 1504-3 Standards for Class R4 repair mortars.

\section{Water absorption}

The capillary water absorption test was carried out over a 24-hour period for the three investigated mortars. The capillary absorption coefficient values after the 24-hour ranged between 0.30 and $0.48 \mathrm{~kg} / \mathrm{m}^{2} / \mathrm{h}^{0.5}$, as shown in Fig. 9. The lowest capillary absorption coefficient of $0.30 \mathrm{~kg} / \mathrm{m}^{2} / \mathrm{h}^{0.5}$ was obtained by the SCRM-20NP ( $27 \%$ less than the SCRM- 0 ), which indicates a lower porosity. Najimi et al. [14] reported that NP can reduce significantly the concrete porosity due to its filling effect and pozzolanic reaction (the formation of secondary $\mathrm{C}-\mathrm{S}-\mathrm{H}$ gel), which can reduce the water mobility inside the mortar matrix and hence, reduce the capillary absorption. On the other side, the highest capillary absorption coefficient was obtained by the SCRM-10LD $\left(0.48 \mathrm{~kg} / \mathrm{m}^{2} / \mathrm{h}^{0.5}\right)$. This might have occurred due to the lake of the LD particles to block effectively the capillary pores. As a conclusion, all of the tested mortar samples meet the requirement for class R4 according to the EN 1504-3. The EN 1504-3 specifies $0.5 \mathrm{~kg} / \mathrm{m}^{2} / \mathrm{h}^{0.5}$ as an upper limit for the water absorption after $24 \mathrm{~h}$ of testing.

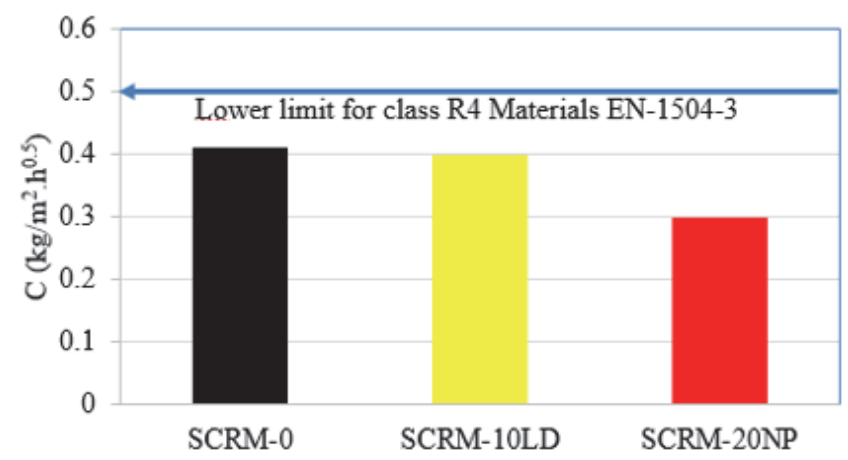

Figure 9: Evolution of water absorption after 24 hours for SCRMs.

\section{Slant-shear strength}

Tab. 3 presents the development of bond strength in the various composite cylinders specimens (SCRMs/SUBC) at 7 and 28-days. At all ages, the slant shear strength values of composite cylinders SCRM-10LD/SUBC and SCRM-20NP/SUBC were less than the control composite specimens SCRM-0/SUBC. The 7-days slant shear strength of the control composite specimens was $20.1 \mathrm{MPa}$, whereas SCRM-10LD/SUBC and SCRM-20NP/SUBC specimens showed a decrease of $10 \%$ and $28 \%$, respectively, compared to the control composite specimens. At 28-days, the bond strength values of SCRM10LD/SUBC and SCRM-20NP/SUBC specimens kept on increasing and reached $21.1 \mathrm{MPa}$ and $20.4 \mathrm{MPa}$, respectively, which are $9 \%$ and $12 \%$ lower than that of the SCRM-0/SUBC. The slant shear strength improvement of SCRM10LD/SUBC specimens could be explained by the higher stiffness (higher $\mathrm{E}_{\mathrm{D}}$ ) of repair material with 10\% LD (SCRM10) than the mortar containing $20 \%$ NP (SCRM-20NP). Another explanation for this, that the textural shape and angularity of the LD particles can increase the friction at the interface between repair material (SCRM-10LD) and existing concrete, thus leading to an improvement of the bond strength [50]. Furthermore, the significant bond strength gain of SCRM-20NP/SUBC composite at 28-days, as seen in Tab. 3 (up to 2 times larger than that of the SCRM-10LD/SUBC) may be due to the high pozzolanic effect that improved the microstructure at the ITZ between the SCRM-20NP mix and SUBC.

Besides, the slant shear test, composite cylinder specimens showed two different failure modes (please see Tab. 4), monolithic failure and failure in the substrate. At 7-days, all composite cylinder specimens exhibited a monolithic rupture mode, where cracking and fracturing can be observed in both the repair materials and substrate concrete. At 28-days, all the fractures were occurred in the substrate concrete, which clearly indicated that the substrate concrete was weaker than the produced repair materials.

Based on the results presented in Tabs. 3 and Fig. 10, it can be concluded that using 10\% LD or 20\% NP are considered as suitable materials for use as cement replacement to produce self-compacting repair mortars, because all the repair materials developed in this study using LD and NP, meet the standards requirements for ACI [51]. 


\begin{tabular}{ccc}
\hline \multirow{2}{*}{ Composite samples } & \multicolumn{3}{c}{ Slant-shear strength } \\
& 7-days & S, MPa \\
SCRM-0/SUBC & 20.1 & 23.2 \\
SCRM-10LD/SUBC & 18.2 & 21.1 \\
SCRM-20NP/SUBC & 14.5 & 20.4 \\
ACI Bond strength range & $6.9-12.4$ & $13.8-20.1$ \\
\hline
\end{tabular}

Table 3: Slant shear strength results.
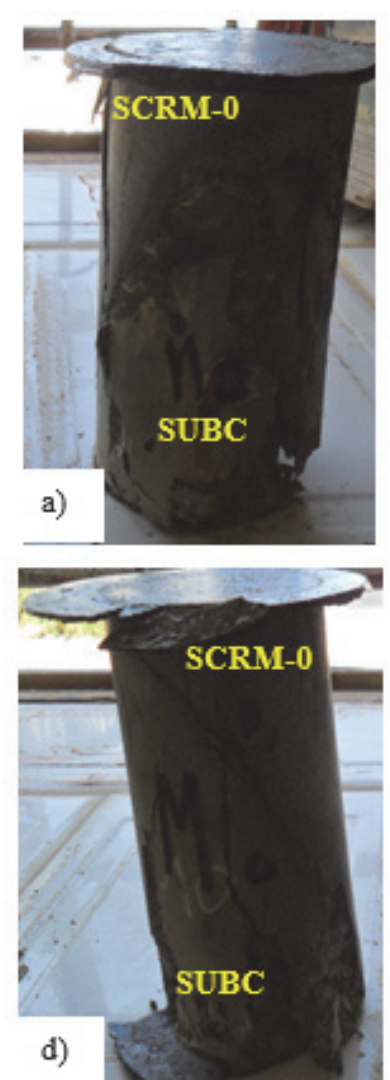

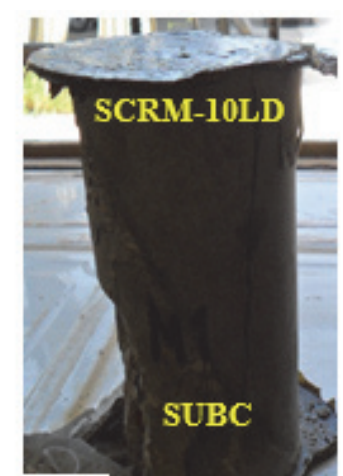

b)

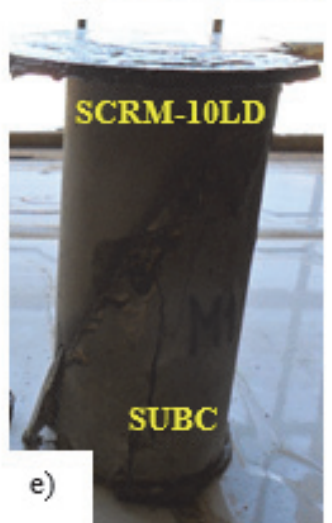

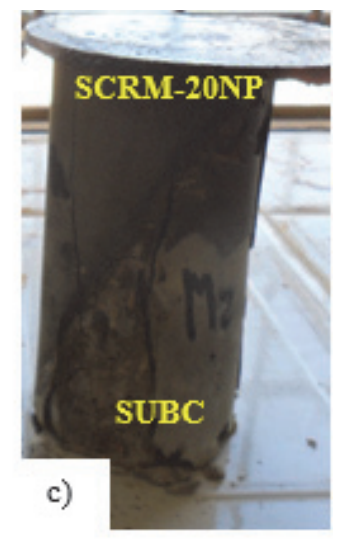

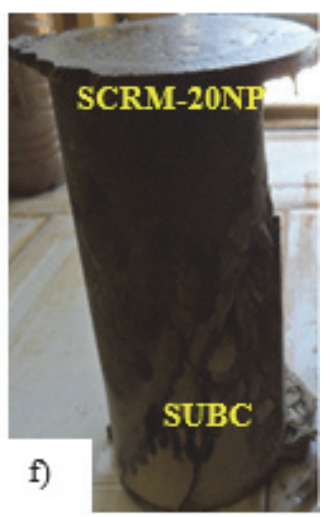

Table 4: Failure mode for composite samples in slant-shear test (a), (b) and (c) monolithic failure at 7-days, and (d), (e) and (f) substrate failure at 28-days

\section{CONCLUSIONS AND FUTURE TRENDS}

he main conclusions according to the experimental results are summarized next:

1) It has been observed that the efficiency of modified polycarboxylic SCWMs decreases compared to the control mortar with replacement cement content up to $10 \%$ LD, and vice-versa, with NP content up to $20 \%$, in comparison with control mortar mix.

2) Although the density of the LD is higher than the NP, the use of $10 \%$ of LD in the SCRM-10NP mix has no significant effect on the wet density compared to the $20 \%$ NP in the SCRM-20NP mix, due to the higher fineness of the NP which leads to a higher matrix densification. 
3) Both limestone dust and natural pozzolan affect the compressive strength of SCRMs mix. At 1-day of curing, the compressive strength of SCRM-10 LD was close $(16.87 \mathrm{MPa})$ to that of control mortar (17.34 MPa). From 7 to 28 -days, using $20 \% \mathrm{NP}$ contributes significantly to the strength development of the SCRM-20NP mix, compared to that of the mortar containing LD. The compressive strength of SCRM-20NP was $47 \mathrm{MPa}$ and kept on increasing and reached 56 $\mathrm{MPa}$ at 28-days of curing with only $3 \%$ decrease compared to that of the control mortar (57.6 MPa). However, all the produced repair mortars showed compressive strength values higher than the lower limit of the Class R4 (EN 1504-3).

4) The dynamic modulus of elasticity decreases with increasing the substitution rate of cement with LD and NP. The incorporation of $10 \%$ of LD led to an increase in the ED at 7 and 28 days higher than $20 \% \mathrm{NP}$ addition. It should be noted that at 28 days, all repair mortars produced, showed higher $E_{D}$ than the lower limit $(20 \mathrm{GPa})$ specified by the EN 1504-3 Standard for Class R4.

5) For a good durability of repair materials used in structural applications as Class R4. EN 1504-3 standard requires maximum water absorption value $0.5 \mathrm{~kg} / \mathrm{m} 2 / \mathrm{h} 0.5$ at $24 \mathrm{~h}$. This study showed that all tested repair mortars meet this requirement. The SCRM-20NP exhibited the lowest capillary absorption coefficient than SCRM-10LD, due to the filling effect of ultrafine particles and the pozzolanic reaction (the formation of secondary $\mathrm{C}-\mathrm{S}-\mathrm{H}$ gel) of the NP.

6) In 7-days slant shear tests, it has been noticed an increment of bond strength in shear of the SCRM-10LD/SUBC specimens. But after this age (28-days), a slight increase of bond strength value was observed. Whereas, the SCRM20NP/SUBC specimens showed a bond strength gain two times larger than that of the SCRM-10LD/SUBC at 28-days. Additionally, all composite specimens exhibited monolithic rupture mode at 7-days and substrate failure at 28-days without interface failure between repair materials and substrate.

Finally, it is important to note that this study does not cover all the required characteristics to examine repair materials for damaged concrete structures. Furthers investigations on compatibility issues such as dimensional change/stability of the self-compacting repair mortars-based LD or NP are recommended.

\section{REFERENCES}

[1] Schlangen, E. and Joseph, C. (2009). Self-healing Processes in Concrete. Self-healing materials fundamentals, design strategies and applications, S. K. Ghosh Ed, Willey Press, Weinheim, pp. 141-179. DOI: $10.1002 / 9783527625376 . c h 5$.

[2] Yazıc1, S., Arel, H. Ş. and. Tabak, V. (2013). The effects of impact loading on the mechanical properties of the SFRCs. Construction and Building Materials, 41, pp. 68-72. DOI : 10.1016/j.conbuildmat.2012.11.095.

[3] Singh, S., Shukla, A. and brown, R. (2004). Pullout behavior of polypropylene fibers from cementitious matrix. Cement and Concrete Research, 34, pp. 1919-1925. DOI: 10.1016/j.cemconres.2004.02.014.

[4] Kuder, K.G., Ozyurt, N., Mu, E.B. and Shah, S.P. (2007). Rheology of fiber-reinforced cementitious materials. Cement and Concrete Research. 37, pp. 191-199. DOI: 10.1016/j.Cem.Con.Res.2009.08.032.

[5] Kanadasan, J., Fauzi, A.F.A., Razak, H.A., Selliah, P., Subramaniam, V. and Yusoff, S. (2015). Feasibility studies of palm oil mill waste aggregates for the construction industry. Materials. 8, pp. 6508-6530. DOI: 10.3390/ma8095319

[6] Courard, L., Darimont, A., Willem, X., Geers, C. and Degeimbre, R. (2002). Repairing concretes with self-compacting concrete: testing methodology assessment. Proceeding of the first North American conference on the design and use of self-consolidating concrete, pp. 267-274. http: hdl.handle.net/2268/59165.

[7] Cyr, M., Legrand, C. and Mouret, M. (2000). Study of the shear thickening effect of superplasticizers on the rheological behavior of cement paste containing or not mineral admixtures. Cement and concrete research, 30, pp. 1477-1483. DOI: 10.1016/S0008-8846(00)00330-6.

[8] Khayat, K.H. and De Schutter, G. (2014). Mechanical properties of self-compacting concrete. RILEM State-of-theArt Reports, pp. 271, ISBN: 978-3-319-03245-0.

[9] Erdoğan, T.Y. (1997). Admixture for Concrete. METU Press. Turkey.

[10] Azad, S. A and Mittal, A. (2006). The Stone quarrying industry around Delhi-impact on Worker and the Environment.

[11] Zhu, W., and Gibbs, J. C. (2005). Use of different limestone and chalk powders in self-compacting concrete. Cement and Concrete Research, 35, pp. 1457-1462, DOI: 10.1016/j.cemconres.2004.07.

[12] Felekoglu, B., Tosun, K., Baradan, B., Altun, A. and Uyulgan, B. (2006). The effect of fly ash and limestone fillers on the viscosity and compressive strength of self-compacting repair mortars. Cement and Concrete Research, 36, pp. 1719-1726. DOI:10.1016/j. cemconres.2006.04.002. 
[13] Dehwah, H.A.F. (2011). Mechanical properties of self-compacting concrete incorporating quarry dust powder, silica fume or fly ash. Construction and Building Materials, 26, pp. 47-551. DOI: 10.1016/j.conbuildmat.2011.06.056.

[14] Najimi, M., Sobhani, J., Ahmadi, B. and Shekarchi, M. (2012). An experimental study on durability properties of concrete containing zeolite as a highly reactive natural pozzolan. Construction and Building Materials, 35, pp. 10231033. DOI: $10.1016 /$ j.conbuildmat.2012.04.038.

[15] Meyer, C. (2009). The greening of the concrete industry. Cement and Concrete Composites, 31, pp. $601-605$. DOI:10.1016/j. cemconcomp.2008.12.010.

[16] Ghrici, M., Kenai, S., Said Mansour, M., and Kadri, E. (2006). Some engineering properties of concrete containing natural pozzolana and silica fume. Journal of Asian Architecture and Building Engineering. 5, pp. 349-354. DOI: $10.3130 /$ jaabe.5.349.

[17] Kaid, N., Cyr, M., Julien, S. and Khelafi, H. (2009). Durability of concrete containing a natural pozzolan as defined by a performance-based approach. Construction and Building Materials, 23, pp.3457-3467. DOI: $10.1016 /$ j.conbuildmat.2009.08.002.

[18] Belaidi, A., Azzouz, L., Kadri, E. and Kenai, S. (2012). Effect of natural pozzolana and marble powder on the properties of self-compacting concrete. Construction and Building Materials, 31, pp. 251-257.

DOI : 10.1016/j.conbuildmat.2011.12.109.

[19] Behfarnia, K. and Farshadfar, O. (2013). The effects of pozzolanic binders and polypropylene fibers on durability of SCC to magnesium sulfate attack. Construction and Building Materials, 38, pp. 38:64-71. DOI: $10.1016 /$ j.conbuildmat. 2012.08.035.

[20] Shamsad, A., Saheed, A., Maslehuddin, M., Kalam, A. (2014). Properties of self-consolidating concrete made utilizing alternative mineral fillers. Construction and Building Materials, 68, pp. 268-276. DOI: $10.1016 /$ j.conbuildmat.2014.06.096.

[21] Saheed, A., Shamsad, A., Maslehuddin, M. and Al-Gahtani, HJ. (2015). Properties of SCC prepared using natural pozzolana and industrial wastes as mineral fillers. Cement and Concrete Composites, 62, pp.125-133. DOI:10.1016/j. cemconcomp.2015.06.001.

[22] EN 197-1(2000). Cement, Composition, specifications and conformity criteria for common cements.

[23] EN 934-2 (2009). Admixtures for concrete, mortar and grout - Part 2: Concrete admixtures - Definitions, requirements, conformity, marking and labeling.

[24] EFNARC. (2005). The European guidelines for self-compacting concrete: specification, production and use. European federation for specialist construction chemicals and concrete systems.

[25] EN 1015-6 (1999). Methods of test for mortar for masonry. Determination of bulk density of fresh mortar.

[26] EN 12190-6 (1999). Products and systems for the protection and repair of concrete structures-Test methodsDetermination of compressive strength of repair mortar.

[27] EN 12504-4 (2004). Testing concrete. Determination of ultrasonic pulse velocity.

[28] EN 1015-18. (2002). Methods of test for mortar for masonry. Determination of water absorption coefficient due to capillary action of hardened mortar.

[29] ASTM C882. (1999). Standard test method for bond strength of epoxy-resin systems used with concrete by slant shear.

[30] Climaco, J. and Regan, P. (1989). Evaluation of bond strength between old and new concrete Proc. 4th Int. Conf. on Structural Faults and Repair, London, pp.115-122. DOI: https://doi.org/10.1680/macr.2001.53.6.377.

[31] Knab, L. and Spring, C. (1989). Evaluation of test methods for measuring the bond strength of Portland cement based repair material to concrete. Cement and Concrete Aggregate, 11, pp. 3-14. DOI: 10.1520/CCA10096J.

[32] Castillo, L. S. and Aguado, de C. A. (2012). Bi-layer diaphragm walls: Evolution of concrete-to-concrete bond strength at early ages. Construction and Building Materials, 31, pp. 29-37. DOI: 10.1016/j.conbuildmat.2011.12.090.

[33] Santos, D. S., Santos, P. M. D., and Dias-da-Costa D. (2012). Effect of surface preparation and bonding agent on the concrete-to-concrete interface strength. Construction and Building Materials, 37, pp. 102-110. DOI: $10.1016 /$ j.conbuildmat.2012.07.028.

[34] ASTM C39-03. (2003). Standard Test Method for Compressive Strength of Cylindrical Concrete Specimens.

[35] Fujiwara, H., Nagataki, S., Otsuki, N. and Endo, H. (1996). Study on reducing unit powder content on high-fluidity concrete by controlling powder particle size distribution. Proceeding of Japan Society of Civil Engineering, 30, pp.117-127. DOI:10.2208/jscej.1996.532_67.

[36] Ellerbrock, H. G., and Spung, S. (1990). Particle size distribution and properties of cement: part III influence of grinding process. Zement-Kalk-Gips, 43, pp.13-19.

[37] Uzal, B., Turanli, L., Mehta, PK. (2007). High-volume natural pozzolan concrete for structural applications. ACI 
Materials Joural, 104, N0 5, pp. 535-8.

[38] Feng, N., Li, G. and Zang, X. (1990). High-strength and flowing concrete with a zeolitic mineral admixture., Cemet and Concrete Aggregate, 12, pp. 61-69. DOI: 10.1520/CCA10273J.

[39] Kaid, N., Cyr., M. and Khelafi, H. (2015). Characterization of an Algerian natural pozzolan for its use in eco-efficient cement. International Journal of Civil Engineering, 13(4A), http: ijce.iust.ac.ir/article-1-974-en.html. DOI: 10.22068/IJCE.13.4.444.

[40] Benabed, B., Soualhi, H., Belaidi, A. S. E., Azzouz, L. and Kenai, S. (2016). Effect of limestone powder as a partial replacement of crushed quarry sand on properties of self-compacting repair mortars. Journal of Building Materials and Structures, 1, pp.15-30.

[41] Shannag, M J. (2000). High strength concrete containing natural pozzolan and silica fume. Cement and Concrete Composite, 22, pp. 399-406. DOI: 10.1016/S0958-9465(00)00037-8.

[42] Bonavetti, V., Donza, H., Rahhal, V. and Irassar, E. (2000). Influence of initial curing on the properties of concrete containing limestone blended cement. Cement and Concrete Research, 30, pp. 703-708.

DOI: $10.1016 /$ S0008-8846(00)00217-9.

[43] Temiz, H., Kantarc1, F. (2014). Investigation of durability of CEM II B-M mortars and concrete with limestone powder, calcite powder and fly ash, Construction and Building Materials, 68, pp. 517-524. DOI:10.1016/j. conbuildmat.2014.06.078.

[44] Lemonis, N., Tsakiridis, P.E, and Katsiotis, N.S., Antiohos, S., Papageorgiou, D., Katsiotis, M.S. and Beazi-Katsioti, M. (2015). Hydration study of ternary blended cements containing ferronickel slag and natural pozzolan. Construction and Building Materials, 81, pp. 130-139. DOI: 10.1016/j.conbuildmat.2015.02.046.

[45] Lawrence, P., Cyr, M. and Ringot, E. (2005). Mineral admixtures in mortars effect of type, amount and fineness of fine constituents on compressive strength. Cement and Concrete Research, 35, pp. 1092-1005. DOI: 10.1016/j.cemconres.2004.07.004.

[46] Guru, J.J., Sashidhar, C., Ramana, R.I.V., Annie, P. J. (2013). Micro and macrolevel properties of fly ash blended selfcompacting concrete. Materials and Design, 46, pp. 696-705. DOI: 10.1016/j.matdes.2012.11.027.

[47] Sarıdemir, M. (2013). Effect of silica fume and ground pumice on compressive strength and modulus of elasticity of high strength concrete. Construction and Building Materials, 49, pp. 484-489. DOI: 10.1016/j.conbuildmat.2013.08.091.

[48] EN 1504-3 (2006). Products and systems for the protection and repair of concrete structures. Definitions, requirements, quality control and evaluation of conformity. Structural and non-structural repair.

[49] Turk, K. (2012). Viscosity and hardened properties of self-compacting mortars with binary and ternary cementitious blends of fly ash and silica fume. Construction and Building Materials, 37, pp. 326-334.

DOI:10.1016/j. conbuildmat.2012.07.081.

[50] Aliabdo, A. and Elmoaty, M. A. (2012). Experimental investigation on the properties of polymer modified SCC. Construction and Building Materials, 34, pp. 584-592. DOI: 10.1016/j.conbuildmat.2012.02.067.

[51] ACI Committee 546. (2004). Concrete repair guide (ACI 546R-04). American Concrete Institute, Farmington. 